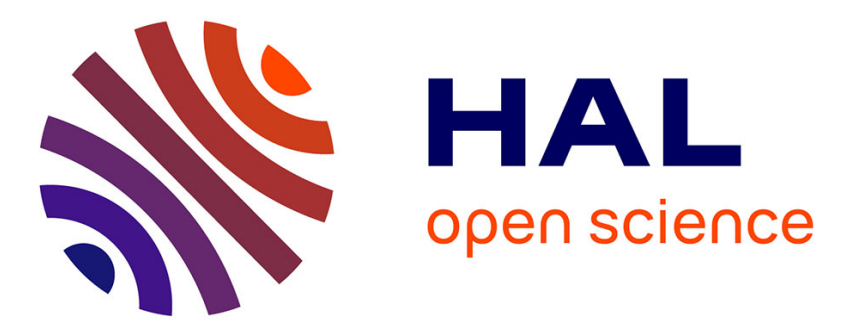

\title{
Euseius gallicus Kreiter and Tixier (Acari: Phytoseiidae) is present in four more countries in Europe: Belgium, Germany, the Netherlands and Turkey
}

\author{
I. Döker, J. Witters, J. Pijnakker, C. Kazak, M. S. Tixier, S. Kreiter
}

\section{- To cite this version:}

I. Döker, J. Witters, J. Pijnakker, C. Kazak, M. S. Tixier, et al.. Euseius gallicus Kreiter and Tixier (Acari: Phytoseiidae) is present in four more countries in Europe: Belgium, Germany, the Netherlands and Turkey. Acarologia, 2014, 54 (3), pp.245-248. 10.1051/acarologia/20142132 . hal-01565301

\section{HAL Id: hal-01565301 \\ https://hal.science/hal-01565301}

Submitted on 19 Jul 2017

HAL is a multi-disciplinary open access archive for the deposit and dissemination of scientific research documents, whether they are published or not. The documents may come from teaching and research institutions in France or abroad, or from public or private research centers.
L'archive ouverte pluridisciplinaire HAL, est destinée au dépôt et à la diffusion de documents scientifiques de niveau recherche, publiés ou non, émanant des établissements d'enseignement et de recherche français ou étrangers, des laboratoires publics ou privés.

\section{(1) (1) $\$$}

Distributed under a Creative Commons Attribution - NonCommercial - NoDerivatives 44.0 


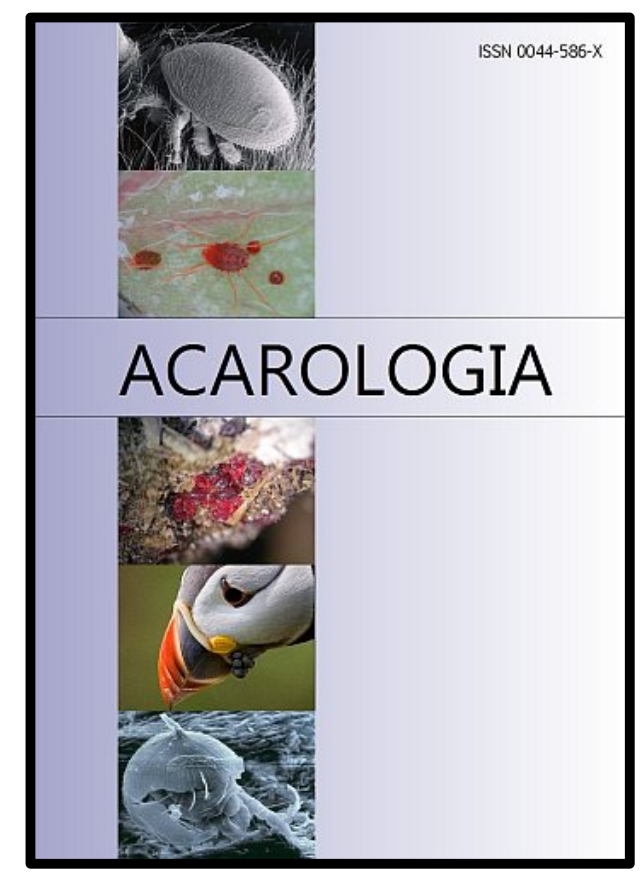

\section{ACAROLOGIA}

A quarterly journal of acarology, since 1959

Publishing on all aspects of the Acari

All information:

http://www1.montpellier.inra.fr/CBGP/acarologia/ acarologia@supagro.inra.fr

\section{OPEN ACCESS}

\section{Acarologia is proudly non-profit, with no page charges and free open access}

Please help us maintain this system by encouraging your institutes to subscribe to the print version of the journal and by sending us your high quality research on the Acari.

Subscriptions: Year 2017 (Volume 57): $380 €$ http://www1.montpellier.inra.fr/CBGP/acarologia/subscribe.php

Previous volumes (2010-2015): $250 € /$ year (4 issues)

Acarologia, CBGP, CS 30016, 34988 MONTFERRIER-sur-LEZ Cedex, France

The digitalization of Acarologia papers prior to 2000 was supported by Agropolis Fondation under the reference ID 1500-024 through the « Investissements d'avenir » programme

(Labex Agro: ANR-10-LABX-0001-01)
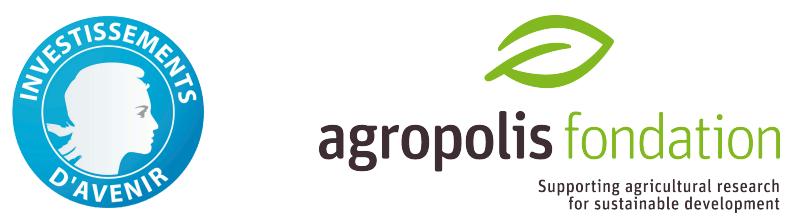

Acarologia is under free license and distributed under the terms of the

Creative Commons-BY-NC-ND which permits unrestricted non-commercial use, distribution, and reproduction in any medium, provided the original author and source are credited. 

FOUR MORE COUNTRIES IN EUROPE: BELGIUM, GERMANY, THE NETHERLANDS AND TURKEY

\author{
İsmail DÖKER ${ }^{1 *}$, Johan WITTERs ${ }^{2}$, Juliette PIJNAKKER ${ }^{3}$, Cengiz KAZAK ${ }^{1}$, \\ Marie-Stéphane TIXIER ${ }^{4}$ and Serge KREITER ${ }^{4}$
}

\author{
(Received 16 January 2014; accepted 04 July 2014; published online 30 September 2014) \\ ${ }^{1}$ Çukurova University Agricultural Faculty, Plant Protection Department, Acarology Lab., 01330 Adana/Turkey. \\ idoker@cu.edu.tr (*Corresponding author),ckazak@cu.edu.tr \\ ${ }^{2}$ Institute for Agricultural and Fisheries Research (ILVO), Plant-Crop Protection, Burg. Van Gansberghelaan 96, 9820 Merelbeke, Belgium. \\ johan.witters@ilvo.vlaanderen.be \\ ${ }^{3}$ Biobest Belgium Bv., Ilse Velden 18, 2260 Westerlo, Belgium. juliette.pijnakker@biobest.be \\ ${ }^{4}$ Montpellier SupAgro, Unité Mixte de Recherche Centre de Biologie pour la Gestion des Populations INRA/IRD/CIRAD/Montpellier SupAgro, \\ Campus International de Baillarguet, CS 30016, 34988 Montferrier-sur-Lez cedex, France.tixier@supagro.inra.fr, kreiter@supagro.inra.fr
}

ABSTRACT - Euseius gallicus is reported from four additional European countries: Belgium, Germany, the Netherlands and Turkey. It is recorded from 4 plant species belonging to 4 families (Convolvulaceae, Malvaceae, Rosaceae and Solanaceae). Measurements based on collected adult females are provided. Finally, comparisons and further observations of type specimens have shown some mistakes on leg chaetotaxy to the original description. The corrected chaetotactic formula is therefore provided.

KEYWORDS - new record; distribution; plants; morphometry; predatory mites

\section{INTRODUCTION}

The genus Euseius was defined by Wainstein in 1962 with the type species Seiulus finlandicus Oudemans, 1915 (Wainstein 1962). This genus is one of the largest genera in the sub-family Amblyseiinae (Acari: Mesostigmata) with more than 188 valid species (Moraes et al. 2004; Chant and McMurtry 2007; Tixier et al. 2009).
Euseius species are considered as specialized pollen feeders and generalist predators (Croft et al. 1997, McMurtry et al. 2013). Some of them, such as E. scutalis (Athias-Henriot, 1958) and E. stipulatus (Athias-Henriot, 1960) are of great importance for Integrated Pest Management (IPM) programs in Mediterranean citrus orchards (i.e. Kasap and Sekeroglu 2004; Papadoulis et al. 2009). Euseius gal- 
TABLE 1: Mean, minimum and maximum measurements of females of Euseius gallicus Kreiter and Tixier collected from Belgium, the Netherlands, Turkey and those reported in the original description.

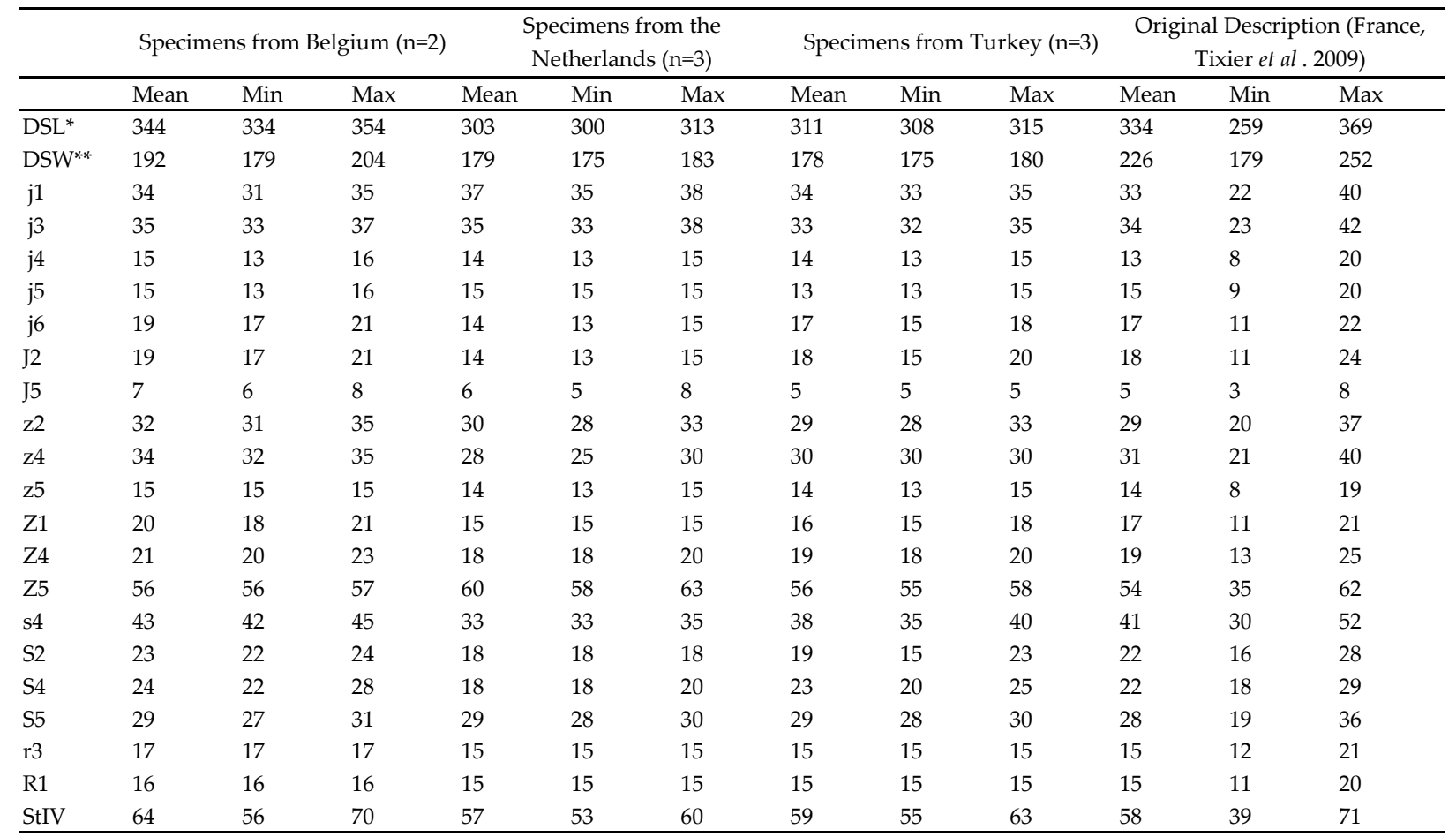

* Dorsal shield length (DSL)

** Dorsal shield width (DSW)

licus Kreiter and Tixier 2009 was recently collected and described from France (Tixier et al. 2009). Some field experiments conducted in The Netherlands and France showed that it is one of the most important promising candidates for augmentative biological control of Frankliniella occidentalis (Pergande, 1895) (Thysanoptera: Thripidae) and Trialeurodes vaporariorum (Westwood, 1856) (Hemiptera: Aleyrodidae). In addition, E. gallicus have been available commercially in international markets since January 2014 (Pijnakker and Gui 2013).

This study presents (i) new records of E. gallicus from Belgium, Germany, the Netherlands, and Turkey and (ii) some corrections of some morphological features reported in the original description. Measurements (with the exception of German specimens) of adult females are also provided in order to assess intraspecific variations and to secure further diagnosis.

\section{MATERIALS AND METHODS}

The specimens were collected on 4 plant species belonging to 4 families. Phytoseiid mites were stored in $95 \%$ ethanol and were then cleared in lactophenol solution for 5 hours. The permanent slides were made using Hoyer's medium and kept in a hot plate $\left(50{ }^{\circ} \mathrm{C}\right)$ during two weeks.

The taxonomic system for the identification is based on Chant and McMurtry (2005; 2007). Setae nomenclature follows that proposed by Lindquist and Evans (1965) as adapted by Rowell et al. (1978) for the family Phytoseiidae. Measurements were performed using a Leica DM 2500 microscope with 400X magnification. All measurements are given in micrometers $(\mu \mathrm{m})$. Because authors do not have permanent slides of German specimens, no measurements were done. 


\section{RESULTS}

New records for Belgium, Germany, the Netherlands and Turkey Euseius gallicus Kreiter and Tixier Euseius gallicus Kreiter and Tixier 2009, in Tixier et al.: 242. Type specimens Montpellier, France, on sour cherry Prunus cerasus L. (Rosaceae).

New records from Belgium 4 우, 2 ○' $0^{7}$, 27.09.2011, Destelbergen $\left(51^{\circ} 4^{\prime} 17^{\prime \prime} \mathrm{N}, 3^{\circ} 49^{\prime} 1^{\prime \prime} \mathrm{E}\right)$, on Tilia cordata (Miller) (Malvaceae), Coll. J. Witters.

New records from Germany 10 우, $50^{7} 0^{7}$, 27.10.2011, Hohenheim (48 $42^{\prime} 43^{\prime \prime}$ N, 9 $9^{\circ} 12^{\prime} 20^{\prime \prime}$ E), on Lycium barbarum L. (Solanaceae), Coll. $\mathrm{H}$. Schneller. (K. M. Schrameyer, pers. com., 09.01.2014).

New records from The Netherlands 5 우, $30^{7} 0^{7}, 05$. 10. 2011, Zevenhuizen $\left(52^{\circ} 0^{\prime} 39^{\prime \prime} \mathrm{N}, 4^{\circ} 34^{\prime} 48^{\prime \prime} \mathrm{E}\right)$ on Rosa sp. cv. Red Naomi (Rosaceae), Coll. J. Pijnakker and A. Leman.

New records from Turkey 5 우, $1 \circ^{7}$, 02.07.2012, Boztepe, Trabzon province (40 $59^{\prime} 50^{\prime \prime}$ N, 39 $43^{\prime} 57^{\prime \prime}$ E), Ipomea sp. (Convolvulaceae), Coll. I. Döker.

World distribution France (Okassa et al. 2009; Tixier et al. 2009), Tunisia (Kreiter et al. 2010), Belgium, Germany, The Netherlands and Turkey (this study).

\section{Remarks}

Prior to this study, three species of Euseius namely E. finlandicus, E. scutalis and E. stipulatus were known from Turkey (Şekeroğlu 1984; Faraji et al. 2011). Only E. finlandicus was known in Belgium, Germany and The Netherlands (Miedema, 1987; Moraes et al. 2004).

Morphological characters and measurements of Belgian, Dutch and Turkish specimens of E. gallicus fit those of the original description (Table 1). Low variations in setal length were observed between the specimens herein reported. This comparison allows to ensure a right diagnosis especially for specimens collected far away from the location of type material. Comparing the present specimens with the type specimens we observed, there are some differences in the original description regarding leg chaetotaxy. We thus checked the type specimens (in the Montpellier SupAgro collection) and we observed two mistakes in the original description: the chaetotactic formula of Genu II and III should be changed as $1-2 / 0,2 / 0-2$ and $1-2 / 1,2 / 0-1$, respectively ( 7 setae on each genua and not 6 as indicated in the original description). In addition, the number of setae of genu and tibia IV should be 7 and 6 , respectively (and not 6 and 5 as illustrated in the drawings of original description). However these corrections do not invalidate the species status of $E$. gallicus.

In addition to the species morphologically close to E. gallicus reported in the original description (Euseius longiverticalis (Liang and Ke, 1983), Euseius amissibilis (Meshkov, 1991) and Euseius kirghisicus (Kolodochka, 1979), it should be noted that it is also close to Euseius ucrainicus (Kolodochka, 1979) especially in idiosomal setae but differs from this latter in the peritreme length and spermatheca shape. Furthermore, when E. gallicus was described the descriptors sent specimens to Dr. Kolodochka for him checking the new status of this new species in relation to those he already described, i.e. E. kirghisicus and E. ucrainicus (M.-S. Tixier, pers. Comm. 2014).

This study clearly shows that E. gallicus is widespread in Europe (including some northwestern and southern countries) on a wide range of plants. In general, these plants were colonized by Tetranychus urticae, Frankliniella occidentalis and Trialeurodes vaporariorum. Future studies should be conducted on biology and effectiveness of this predatory mite to control spider mites, thrips and whiteflies.

\section{ACKNOWLEDGEMENTS}

We thank Mr. Martial Douin (Montpellier SupAgro, UMR CBGP) for valuable comments on the manuscript. Mr. Bert Vierbergen (Netherlands Food and Consumer Product Authority) and Mr. K. M. Schrameyer (Landwirtschaftsamt, Heilbronn, Germany) for contact and collection of German specimens, respectively. We also thank the two reviewers for their advices to improve this contribution. 


\section{REFERENCES}

Chant D.A., McMurtry J.A. 2005 - A review of the subfamily Amblyseiinae Muma (Acari: Phytoseiidae): part VI. The tribe Euseiini n. tribe: subtribes Typhlodromalina n. subtribe, Euseiina n. subtribe and Ricoseiina n. Subtribe - Internat. J. Acarol., 31: 187-223. doi:10.1080/01647950508684424

Chant D.A., McMurtry J.A. 2007 - Illustrated keys and diagnoses for the genera and subgenera of the Phytoseiidae of the world (Acari: Mesostigmata) - West Bloomfield, MI: Indira Publishing House. pp. 220.

Croft B.A., Blackwood J.S., McMurtry J.A. 1997 - Classifying life-style types of phytoseiid mites: diagnostic traits - Exp. Appl. Acarol., 33: 247-260. doi:10.1023/B:APPA.0000038622.26584.82

Faraji F., Çobanoğlu S., Cakmak I. 2011 - A checklist and a key for the Phytoseiidae species of Turkey with two new species records (Acari: Mesostigmata) - Internat. J. Acarol., 37: 221-243. doi:10.1080/01647954.2011.558851

Kasap İ., Şekeroğlu E. 2004 - Life history of Euseius scutalis feeding on citrus red mite Panonychus citri at various temperatures - BioControl, 49: 645-654.

Kreiter S., Tixier M.-S., Sahraoui H., Grissa K.L., Chabaan B.S., Chatti A., Chermiti B., Khoualdia O., Ksantini M. 2010 - Phytoseiid mites (Acari: Mesostigmata) from Tunisia: Catalogue, biogeography and key for identification - Tunis. J. Plant Protec., 5: 151-178.

Lindquist E.E., Evans G.O. 1965 - Taxonomic concepts in Ascidae with modified setal nomenclature for idiosoma of Gamasina (Acarina: Mesostigmata) - Mem. Entomol. Soc. Can., 47:1-59.

McMurtry J.A., De Moraes G.J., Sourasso N.F. 2013 Revision of the lifestyles of phytoseiid mites (Acari: Phytoseiidae) and implications for biological control strategies - Syst. Appl. Acarol., 18(4): 297-320.

Miedema, E. 1987 - Survey of phytoseiid mites (Acari: Phytoseiidae) in orchards and surrounding vegetation of northwestern Europe - Neth. J. Plant Pathol., 93 Suppl. 2: 1-64. doi:10.1007/BF01984462

Moraes G.J., McMurtry J.A., Denmark H.A., Campos C.B. 2004 - A revised catalog of the mite family Phytoseiidae - Zootaxa, 434: 1-494.
Okassa M., Tixier M.-S., Cheval B., Kreiter S. 2009 Molecular and morphological evidence for a new species status within the genus Euseius (Acari: Phytoseiidae) — Can. J. Zool., 87: 689-698. doi:10.1139/Z09057

Oudemans A.C. 1915 - Acarologische Aanteekeningen LVI — Entomol. Bericht., 4: 180-188.

Papadoulis G.Th., Emmanouel N.G., Kapaxidi E.V. 2009 - Phytoseiidae of Greece and Cyprus (Acari: Mesostigmata) - West Bloomfield, MI: Indira Publishing House. pp 200.

Pijnakker J., Gui S. 2013 - Dyna-Mite ${ }^{\circledR}$ A revolutionary predatory mite strategy for roses Web Access: [21 October 2013], Available from: http://www.biobest.be/nieuws/289/3/0/

Rowell H.J., Chant D.A., Hansell R.I.C. 1978 — The determination of setal homologies and setal patterns on the dorsal shield in the family Phytoseiidae (Acarina: Mesostigmata) - Can. Entomol., 110: 859-876. doi:10.4039/Ent110859-8

Şekeroğlu E. 1984 — Phytoseid mites (Acarina: Mesostigmata) of Southern Anatolia, their biology, and effectiveness as a biological control agent on strawberry plant - Doğa, 8: 320-336 (in Turkish with English summary).

Tixier M.-S., Kreiter S., Okassa M., Cheval B. 2009 - A new species of the genus Euseius Wainstein (Acari: Phytoseiidae) from France - J. Nat. Hist., 44: 241-254. doi:10.1080/00222930903383529

Wainstein B.A. 1962 - Some new predatory mites of the family Phytoseiidae (Parasitiformes) of the USSR fauna - Entomol. Oboz., 41: 230-240 (in Russian); Entomol. Rev., 41: 139-146 (English translation).

\section{COPYRIGHT}

(oc) EY-No-ND Döker İ. et al. Acarologia is under free license. This open-access article is distributed under the terms of the Creative Commons-BY-NC-ND which permits unrestricted non-commercial use, distribution, and reproduction in any medium, provided the original author and source are credited. 